\title{
Małopłytkowość indukowana protaminą - nowy problem czy inny typ małopłytkowości poheparynowej?
}

\author{
Protamine-induced thrombocytopenia: a new clinical complication \\ or other type of heparin-induced thrombocytopenia?
}

\author{
Joanna Mikłosz, Bartłomiej Kałaska, Emilia Sokołowska, Andrzej Mogielnicki \\ Zakład Farmakodynamiki Uniwersytetu Medycznego w Białymstoku
}

\section{Streszczenie}

Protamina jest powszechnie stosowanym środkiem odwracającym antykoagulacyjne działanie heparyny niefrakcjonowanej, szczególnie po zabiegach kardiochirurgicznych. Najnowsze badania wskazują, że część pacjentów poddanych zabiegowi krążenia pozaustrojowego jest narażona na trombocytopenię w trakcie ekspozycji na heparynę. Wielkocząsteczkowe kompleksy protaminy i heparyny wywołują immunizację i produkcję immunoglobulin G, które aktywują płytki krwi za pośrednictwem receptora Fcylla. Podczas krążenia pozaustrojowego infuzja protaminy u niektórych pacjentów zwiększa ryzyko wczesnych powikłań zakrzepowych, spowodowanych obecnością tych przeciwciał we krwi. W niniejszym przeglądzie skupiono się na pracach, w których przebadano mechanizm aktywacji płytek krwi przez anty-protaminowo-heparynowe przeciwciała. Porównano je z przeciwciałami wywołującymi immunologiczną małopłytkowość poheparynową. Ponadto opisano kliniczne konsekwencje trombocytopenii indukowanej protaminą, czynniki ryzyka i ogólne wytyczne dotyczące terapii powikłań zakrzepowo-zatorowych u pacjentów kardiochirurgicznych.

Słowa kluczowe: protamina, heparyna, trombocytopenia

Folia Cardiologica 2017; 12, 4: 355-361

\section{Wstęp}

Kardiologia inwazyjna jest dziedziną medycyny, w której postęp i innowacyjne rozwiązania wydają się najbardziej zauważalne. Angioplastyczne i trombolityczne metody pozwalające na skuteczną terapię ostrych zespołów wieńcowych osiągnęły wysokie standardy. Zastąpienie płuc i serca wciąż udoskonalanym krążeniem pozaustrojowym (CPB, cardiopulmonary bypass) stało się znaczącym krokiem w rozwoju kardiochirurgii. Mimo zwiększania biozgodności powierzchni stosowanych urządzeń medycznych oraz implantów, wciąż pozostaje problem ich trombogenności, co wymaga hamowania krzepnięcia krwi w czasie i po zabiegach. Niemniej jednak istnieje wiele niewyjaśnionych kwestii wynikających ze skomplikowanego schematu CPB [1].
Konieczność przetłaczania krwi silikonowymi drenami pozbawionymi właściwości śródbłonka naczyniowego wiąże się ze zwiększonym ryzykiem powikłań zakrzepowo-zatorowych. Obok doskonalenia technik operacyjnych i anestezjologicznych jest wymagana przede wszystkim skuteczna i bezpieczna terapia przeciwzakrzepowa. Lekiem pierwszego wyboru stosowanym w trakcie zabiegu CPB jest heparyna niefrakcjonowana, natomiast środkiem odwracającym jej działanie jest wyłącznie siarczan protaminy [2]. Dzięki szybkiej neutralizacji efektu przeciwkrzepliwego heparyny, protamina stanowi podstawę tego zabiegu, niezbędną do osiągnięcia chirurgicznej hemostazy. Taki schemat leczenia wiąże się z zagrażającymi życiu działaniami niepożądanymi, szczególnie powikłaniami immunologicznymi [3]. Infuzja protaminy może prowadzić do formowania się przeciwciał

Adres do korespondencji: mgr farm. Joanna Mikłosz, Zakład Farmakodynamiki, Uniwersytet Medyczny w Białymstoku, ul. Mickiewicza 2c, 15-089 Białystok, tel. 8574856 11, e-mail: joanmiklosz@gmail.com 


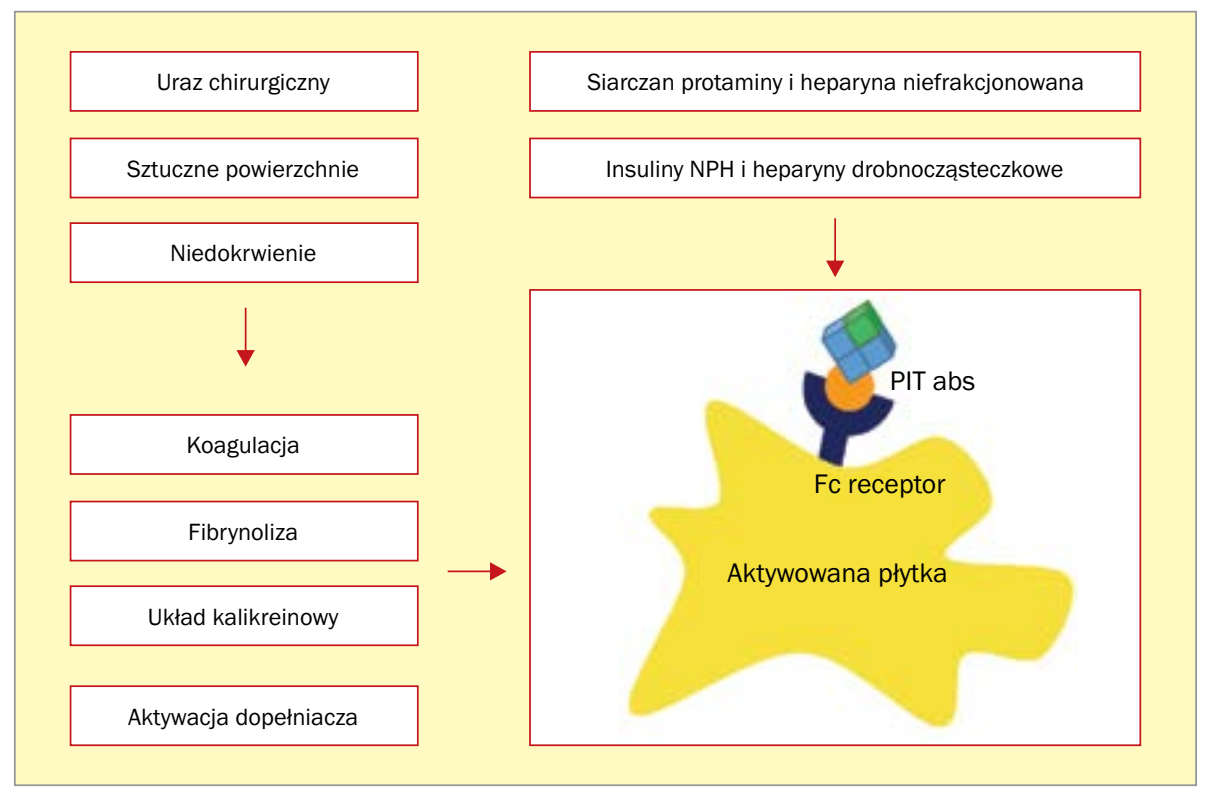

Rycina 1. Czynniki aktywujące płytki krwi podczas krążena pozaustrojowego (CPB, cardiopulmonary bypass); NPH (neutral protamine hagedorn) - insulina izofanowa; PIT abs (PIT antibodies) - przeciwciała przeciwko kompleksowi protamina-heparyna

przeciwko protaminie (PRT abs) i kompleksowi protamina-heparyna (PIT abs), które aktywują płytki krwi poprzez receptor Fcylla, prowadząc do trombocytopenii $[4,5]$. Zarówno heparyna, jak i protamina wykazują udowodniony potencjał immunogenny, a kontakt krwi z silikonowymi drenami podczas CPB dodatkowo prowadzi do uwalniania szeregu mediatorów ostrych i przewlekłych reakcji immunologicznych. Stan, w jakim znajduje się organizm podczas całej procedury, jest utożsamiany z odpowiedzią zapalną wynikającą z procesu chorobowego oraz z zastosowanego schematu leczenia (ryc. 1) [1].

Protamina i PRT abs obecne w organizmie kardiochirurgicznych pacjentów są utożsamiane ze zjawiskiem małopłytkowości indukowanej heparyną (HIT, heparin-induced thrombocytopenia). Wynika to z faktu, że odnotowano zmiany w liczbie płytek krwi po podaniu samej protaminy [6]. Połączenie protaminy i heparyny również indukuje trombocytopenię, co powoduje trudności z ustaleniem etiologii zjawiska [4, 5]. Najnowsze wyniki badań wskazują, że odpowiedź przeciwciał ukierunkowanych na kompleksy protamina-heparyna różni się od wcześniej opisywanych reakcji na samą protaminę. Czy mamy zatem do czynienia z nową jednostką chorobową określaną mianem trombocytopenii indukowanej protaminą (PIT, protamine-induced thrombocytopenia)?

\section{Patogeneza trombocytopenii indukowanej protaminą}

Protamina jest silnie zasadowym, bogatym $\mathrm{w}$ argininę, dodatnio naładowanym białkiem. W medycynie jest wykorzystywana do neutralizacji heparyny niefrakcjonowanej i częściowo heparyn drobnocząsteczkowych oraz jako stabilizator insulin. Inaktywuje katalityczny wpływ heparyny na antytrombinę poprzez tworzenie z nią kompleksów z udziałem wiązań elektrostatycznych [3]. Protamina jest znanym od lat czynnikiem immunizacyjnym. Reakcje anafilaktyczne, hipotensja, skurcz naczyń płucnych z niewydolnością prawokomorową serca są w znacznym stopniu związane z wysokim mianem immunoglobulin IgE, degranulacją komórek tucznych, uwalnianiem histaminy oraz aktywacją układu dopełniacza [3, 7, 8]. Immunogenność protaminy została dokładnie opisana w grupie pacjentów cukrzycowych przyjmujących preparaty insuliny izofanowej (NPH, neutral protamine hagedorn), mężczyzn po wazektomii oraz pacjentów uczulonych na ryby. Przeciwciała przeciwko protaminie (PRT abs) są obecne u 29-38\% pacjentów leczonych NPH i 22-30\% mężczyzn po wazektomii [9-11]. Polikationowa natura protaminy umożliwia jej tworzenie wielkocząsteczkowych kompleksów z anionową heparyną. Chudasama i wsp. przeprowadzili badania na mysim modelu, w których wykazali potencjał immunogenny kompleksu i udowodnili obecność przeciwciał skierowanych przeciw protaminie i heparynie [12]. Wykrycie przez Bakchoul i wsp. PIT abs u kardiochirurgicznych pacjentów potwierdziło przypuszczenia dotyczące zjawiska PIT [5]. W swoich badaniach dowiedli, że aktywacja płytek krwi przez PIT abs jest związana ze znacznie nasiloną trombocytopenią oraz może stanowić ryzyko wczesnych incydentów zakrzepowo-zatorowych u hospitalizowanych pacjentów. Przeciwciała przeciwko kompleksowi protamina-heparyna (PIT abs) wywołują wewnątrznaczyniową aktywację płytek krwi za pośrednictwem receptora płytkowego Fcylla zarówno in vitro, jak i in vivo (mysi model) [13]. Mimo wysokiego 
Tabela 1. Porównanie odpowiedzi immunologicznej i klinicznej w zjawisku małopłytkowości indukowanej heparyną (HIT, heparin-induced thrombocytopenia) i trombocytopenii indukowanej protaminą (PIT, protamine-induced thrombocytopenia)

$\begin{array}{lll} & \text { HIT } & \text { PIT } \\ \text { Antygen } & \begin{array}{l}\text { Czynnik płytkowy 4/ } \\ \text { /heparyna }\end{array} & \text { Protamina/heparyna } \\ \text { Klasa immunoglobulin } & \text { IgG } & \text { IgG } \\ \text { Mechanizm aktywacji płytek krwi } & \text { Receptor Fcylla } & \text { Receptor Fcylla } \\ \text { Czynniki ryzyka } & \text { Heparyna podana w trakcie } & \text { Odwrócenie działania heparyny protaminą w trakcie zabiegu; } \\ & \text { i zaraz po zabiegu } & \text { terapia NPH i heparynami drobnocząsteczkowymi } \\ \begin{array}{l}\text { Wczesna trombocytopenia } \\ \text { i powikłania zakrzepowo-zatorowe }\end{array} & \text { Nie } & \text { Tak } \\ \text { NPH (neutral protamine hagedorn)-insulina izofanowa } & & \end{array}$

współczynnika immunizacji i znaczącej grupy seropozytywnych pacjentów tylko nieznaczna część PIT abs wydaje się mieć znaczenie kliniczne. Za największą chorobotwórczość odpowiadają, tak jak w przypadku HIT, przeciwciała klasy IgG z komponentą aktywującą płytki krwi, w porównaniu z tymi, które nie mają takich właściwości, nawet kiedy są wykrywane zaraz po operacji [14]. Patomechanizm PIT przypomina znany sposób aktywacji trombocytów z udziałem immunoglobulin klasy IgG (HIT abs) skierowanych przeciwko kompleksowi czynnika płytkowego 4 (PF4, platelet factor 4) i heparyny (tab. 1). Czynnik płytkowy 4 jest endogenną, dodatnio naładowaną proteiną zdolną do tworzenia z heparyną w zbliżonych stosunkach molowych, wielkocząsteczkowych, stabilnych kompleksów za pomocą niespecyficznych oddziaływań elektrostatycznych (ok. 670 kDa) [15]. Patogeneza zjawiska HIT nie jest w pełni wyjaśniona. HIT abs oprócz aktywacji trombocytów wpływają także na monocyty i komórki śródbłonka, indukując ekspresję czynnika tkankowego oraz trombiny [14, 16, 17]. Podwyższone stężenie trombiny, a nie sama trombocytopenia, jest główną przyczyną ryzyka zakrzepicy [14]. Prozakrzepowy mechanizm zjawiska HIT może mieć również inne podłoże. Przeciwciała HIT abs utrudniają oddziaływanie PF4 z trombomoduliną, a tym samym wytwarzanie aktywnego białka C. Tetrameryczny PF4 wzmaga wytwarzanie aktywnego białka $\mathrm{C}$ poprzez tworzenie kompleksów z ujemnie naładowanymi ugrupowaniami trombomoduliny. Połączenia PF4 z trombomoduliną wykazują podobieństwa do kompleksów PF4 i heparyny, tym samym HIT abs mogą się z nimi wiązać i w różnym stopniu hamować generacje aktywnego białka C [18].

\section{Obraz kliniczny trombocytopenii indukowanej protaminą}

Małopłytkowość w przebiegu PIT rzadko daje charakterystyczne objawy. Istnieją przypadki kliniczne, w których wystąpienie trombocytopenii jest ściśle związane z obec- nością aktywujących płytki PIT abs [19, 20]. Odnotowano historię czterech pacjentów z gwałtownym spadkiem liczby płytek krwi poniżej 50 tys./ $\mu$ l w przeciągu 2 dni od zakończenia operacji oraz w 5 przypadkach wystąpiły powikłania zakrzepowo-zatorowe [19]. Mimo serologicznych podobieństw między przeciwciałami PIT abs i HIT abs, kliniczna odpowiedź organizmu na każde z nich wydaję się odmienna (tab. 1). U pacjentów z PIT abs efekt aktywacji płytek przypada na moment infuzji protaminy i obejmuje końcową fazę operacji serca. PIT abs mogą być wykrywane już w trakcie operacji. Przeciwnie, HIT abs stają się wykrywalne po około 5 dniach od przeprowadzenia CPB, stąd brak ryzyka wczesnych powikłań zakrzepowych w tym przypadku. Sytuacja ta może również wynikać z protekcyjnego działania heparyny podawanej w dużych dawkach w trakcie zabiegu. Ze względu na krótki okres półtrwania protaminy (ok. $5 \mathrm{~min}$ ) i brak endogennego odpowiednika krążącego w ustroju, zjawisko PIT nie jest opóźnione w czasie tak jak HIT [21, 22]. Krótszy okres trwania PIT dodatkowo determinują inne właściwości przeciwciał. PIT abs nie reaguja krzyżowo z innymi kompleksami, jak ma to miejsce w przypadku HIT abs a PF4 związanym z glikozaminoglikanami na powierzchni płytek krwi [16]. Dodatkowo heparynowy efekt z odbicia jest dowodem na ograniczony czas przebywania kompleksów protaminy i heparyny w ustroju [23]. Ewentualne wydłużenie PIT mogłoby wynikać z faktu, że protamina wiążę się z powierzchnią trombocytów, podobnie jak robi to abciximab, lek przeciwpłytkowy blokujący receptory glikoproteinowe (GP) Ilb/IIla. Dzięki temu znacznie dłużej mogłaby utrzymywać się w organizmie [24]. Jest to tym bardziej prawdopodobne, gdyż wykazano zdolność protaminy do formowania kompleksów z trombocytami i innymi komórkami krwi, czego następstwem było zaobserwowane przejściowe gromadzenie się agregatów znakowanych płytek krwi w płucach i wątrobie $[6,25]$. Wydłużenie zjawiska PIT mogłoby również wynikać z wywołanego PIT abs osłabienia megakariocytopoezy. Jest to obserwowane między innymi w przypadku innego antagonisty receptora glikopro- 
teinowego IIb/IIla - eptifibatidu, który za pośrednictwem przeciwciał anty-GPIIb/Illa redukuje ilość megakariocytów [26]. Wszystkie te zagadnienia wymagają dalszych badań.

\section{Czynniki ryzyka trombocytopenii indukowanej protaminą}

Trzy niezależne zespoły badawcze potwierdziły obecność PIT abs w okresie pooperacyjnym u 26-29\% pacjentów $[4,13,27]$. Serokonwersje zaobserwowano w 6.-10. dniu od zakończenia operacji. Udowodniono zwiększone ryzyko pacjentów przyjmujących preparaty insulinowe z dodatkiem protaminy. Aż 10\% hospitalizowanych wykazało obecność PIT abs, mimo nieodnotowanej ekspozycji na protaminę podczas zabiegów kardiochirurgicznych. PIT abs w sposób zależny od heparyny aktywują płytki krwi w obecności insuliny NPH [28]. Lee i wsp. wykazali, że prawie 80\% PIT abs może wiązać protaminę występującą w insulinowych preparatach [4]. Wcześniejsza ekspozycja pacjentów cukrzycowych na NPH może stanowić czynnik immunizacyjny w rozwoju odpowiedzi immunologicznej na kompleksy protamina-heparyna. Szczególnie dotyczy to pacjentów przyjmujących dodatkowo profilaktycznie heparyny drobnocząsteczkowe. Z klinicznego punku widzenia najważniejszą cechą PIT abs jest ich przemijalność. Przedoperacyjna obecność PIT abs zwiększa pooperacyjną trombocytopenię i może stanowić ryzyko nowych powikłań zakrzepowych. Po około 120 dniach od zabiegu jedynie niewielka grupa pacjentów pozostaje seropozytywna. Brak PIT abs po kilku miesiącach rekonwalescencji pozwala na kolejną ekspozycję organizmu na protaminę i przeprowadzenie bezpiecznej operacji bez ryzyka powikłań.

\section{Postępowanie terapeutyczne}

Trombocytopenia indukowana heparyną występuje u około 1 na 5000 hospitalizowanych pacjentów z dużą zmiennością wśród populacji chorych, natomiast powikłania zakrzepowo-zatorowe pojawiają się u około $50 \%$ ze diagnozowanym HIT. Do najczęstszych powikłań należą zatorowość płucna i zakrzepica żylna kończyn dolnych [29]. Prozakrzepowe następstwa HIT sprawiają, że jego wczesne rozpoznanie jest bardzo istotne. Diagnozę ustala się na podstawię czterostopniowej skali „4Ts” i wyniku testu immunoenzymatycznego stwierdzającego obecność HIT abs [30]. Terapia polega na natychmiastowym odstawieniu leków przeciwkrzepliwych z grupy heparyn oraz antagonistów witaminy $\mathrm{K}[30,31]$. Wybór odpowiedniego środka z puli parenteralnych, nieheparynowych antykoagulantów zależy od funkcji wątroby i nerek chorego oraz jego dostępności na rynku. Bezpośrednie inhibitory trombiny (lepirudyna, biwalirudyna, argatroban) są lekami rekomendowanymi w leczeniu HIT, gdyż nie wiążą się z płytkami krwi oraz białkami osocza. Niestety są to leki drogie o wąskim in- deksie terapeutycznym, a leczenie wymaga ciągłego wlewu dożylnego oraz częstego monitorowania i dostosowywania dawki [31, 32]. W przypadku niedostępności bezpośrednich inhibitorów trombiny należy zastosować inhibitory czynnika Xa (danaparoid, rzadziej fondaparinux). Fondaparinux powinien być rozważany tylko w przypadku braku dostępności innych, alternatywnych leków, ze względu na możliwość wywoływania HIT [33, 34]. Doustny bezpośredni inhibitor trombiny (dabigatran) oraz inhibitory czynnika Xa (riwaroksaban, apiksaban i edoksaban) nie reagują na HIT abs. Dodatkowo w listopadzie 2015 roku po raz pierwszy pomyślnie został zarejestrowany idarucizumab - fragment przeciwciała zdolny do odwrócenia działania dabigatranu. Mimo to grupa doustnych antykoagulantów stanowi niewystarczającą ochronę przeciwzakrzepową i nadal brakuje twardych dowodów na ich skuteczność w terapii HIT [30, 35-37].

Najnowsze metody leczenia HIT znajdują się w fazie badań przedklinicznych i należą do nich między innymi: antagoniści PF4, niepatogenne, monoklonalne przeciwciała HIT abs zakłócające powstanie kompleksów PF4-heparyna oraz blokery FcyRlla uniemożliwiające wiązanie kompleksów HIT z receptorami i aktywację płytek krwi [38, 39].

Trombocytopenia indukowana protaminą jako nowa jednostka chorobowa wymaga dalszych badań niezbędnych do ustalenia postępowania w grupie pacjentów objętych ryzykiem. Obecnym rozwiązaniem jest zastosowanie alternatywy dla siarczanu protaminy. Protamina jest jedynym na rynku środkiem odwracającym działanie heparyny niefrakcjonowanej, częściowo hamującym aktywność heparyn drobnocząsteczkowych i kompletnie nieaktywnym wobec fondaparynuksu. Od lat trwają poszukiwania skutecznego zamiennika, jednak większość z nich zostaje wstrzymana na etapie badań klinicznych ze względów bezpieczeństwa. Najbardziej obiecującymi następcami protaminy wydają się UHRA (universal heparin reversal agents) - będący w fazie badań przedklinicznych oraz andeksanet alfa i aripazine (PER977) - obecnie testowane na pacjentach. Andeksanet alfa - rekombinowane białko i aripazyna - małocząsteczkowy, kationowy związek, hamują aktywność bezpośrednich inhibitorów czynnika Xa, dając szanse na odwrócenie działania heparyn [37, 40]. W wyniku syntezy i licznych modyfikacji chemicznych na przełomie kilku ostatnich lat również grupa autorów niniejszego artykułu opracowała szereg polimerów, z których na podstawie wstępnych badań wyselekcjonowano najbardziej obiecujące zamienniki protaminy. Wśród otrzymanych związków najskuteczniejszym i dobrze tolerowanym okazał się Dex40-GTMAC3 [41-44]. Jednak jego niska aktywność wobec drobnocząsteczkowych heparyn oraz fondaparinuxu skłoniła autorów niniejszego artykułu do opracowania nowej uniwersalnej odtrutki pozwalającej na neutralizację wszystkich parenteralnych antykoagulantów; HBC (heparin-binding copolymer) jest polimerem 
blokowym uzyskanym w wyniku prostej, szybkiej i powtarzalnej syntezy. W badaniach zarówno in vitro, jak i in vivo potwierdzono jego skuteczność i bezpieczeństwo. Na tym etapie badań HBC wykazał przewage nad protaminą, co czyni go jej doskonałym następcą [45].

Jedną z najnowszych metod leczenia PIT i HIT może być wykorzystanie powstałego w wyniku chemicznej modyfikacji cząsteczki heparyny, jej częściowo odsiarczonego produktu (ODSH, 2-0, 3-0-desulfated heparin). Synteza ODSH miała na celu uzyskanie związku o minimalnej aktywności przeciwzakrzepowej z zachowanym przeciwzapalnym działaniem heparyny. Ze względu na zdolność ODSH do tworzenia oddziaływań elektrostatycznych, postanowiono zbadać jego wpływ na zjawisko HIT i PIT. Okazało się, że ODSH zakłóca powstawanie kompleksów między PF4 a heparyną, redukuje ilość zarówno PIT abs, jak i HIT abs, a kompleksy PF4-ODSH nie wykazują reakcji krzyżowej z HIT abs. Potencjalnie ODSH może znaleźć zastosowanie w terapii trombocytopenii indukowanej zarówno heparyną, jak i protaminą $[46,47]$.

\section{Podsumowanie}

Protamina jest lekiem zarejestrowanym ponad 70 lat temu. Dowody na jej toksyczność pochodzą z badań klinicznych, których głównym mankamentem jest mała liczebność mocno zróżnicowanej grupy pacjentów. Większość wyników to poboczne obserwacje skutków terapii, a ich interpretację utrudnia stosowanie innych procedur, które mogą maskować bardziej subtelne efekty terapii farmakologicznej. Ponadto krążenie pozaustrojowe ze względu na swoją skomplikowaną procedurę jest samo w sobie silnym bodźcem prozakrzepowym, który prawdopodobnie zostaje potęgowany przez zaaktywowane PIT abs płytki krwi. W związku z możliwym zwiększeniem ryzyka groźnych powikłań oraz wieloma innymi poważnymi działaniami niepożądanymi, podanie pro- taminy może wywoływać obawy u lekarzy. Każdy negatywny wpływ na płytki krwi w trakcie zabiegów wiąże się z dużym niebezpieczeństwem. W ostatnich badaniach wskazano wyraźnie na istnienie zjawiska PIT. Mimo interesujących wyników uzyskanych w badaniach klinicznych, brakuje dowodów na objawową obecność PIT. Nie jest łatwo wyeliminować wpływu samego krążenia pozaustrojowego na trombocytopenię. W warunkach klinicznych podawanie pacjentom samej protaminy jest niemożliwe, zatem nie wiadomo, czy obserwowane zjawisko dotyczy tylko kompleksów, czy może samej protaminy. Ponadto wpływ PRT abs w patogenezie zjawiska PIT nadal pozostaje niewyjaśniony. Brak standaryzacji testów laboratoryjnych w kierunku przeciwciał PIT wywołuje trudności w interpretacji wyników badań. Istotne jest także dokładne ustalenie czynników ryzyka immunizacji, na przykład czy pacjenci z cukrzycą przyjmujący insulinę NPH są bardziej narażeni na wystąpienie PIT? Szersze badania są niezbędne do ustalenia skutków wystąpienia PIT, takich jak ryzyko incydentów zakrzepowo-zatorowych, wzajemnego oddziaływania HIT abs i PIT abs oraz ich wspólnego wpływu na małopłytkowość i jej powikłania. W celu dokładniejszego zbadania znaczenia klinicznego PIT abs oraz częstości występowania należałoby przeprowadzić większe badania prospektywne. Poznanie istoty zjawiska PIT mogłoby mieć duże znacznie praktyczne, na przykład w selekcji pacjentów poddawanych zabiegom kardiochirurgicznym.

\section{Finansowanie}

Joanna Mikłosz otrzymała finansowanie z projektu nr N/ST/MN/17/002/2211 Uniwersytetu Medycznego w Białymstoku.

\section{Konflikt interesów}

Autorzy nie zgłaszają konfliktu interesów.

\section{Abstract}

Protamine is widely used to neutralize the anticoagulant effects of unfractionated heparin, particularly after cardiac surgery. Recent reports suggest that some patients undergoing cardiopulmonary bypass exposed to heparin and protamine may develop thrombocytopenia. Multimolecular protamine-heparin complexes lead to immunization and production of immunoglobulin $\mathrm{G}$ class antibodies that may activate platelets through Fcylla receptors. Some patients injected with protamine during cardiopulmonary bypass have increased the risk of early thromboembolic events due to the presence of these antibodies in the blood. In the present review, we will focus on studies investigating the mechanism of platelet activation by anti-protamine-heparin antibodies. We will compare antibodies that are associated with immune heparin-induced thrombocytopenia. In addition, we will describe the clinical consequences of protamine-induced thrombocytopenia, risk factors and general guidelines for management of thromboembolic complications in the post-cardiac surgery patients.

Key words: protamine, heparin, thrombocytopenia

Folia Cardiologica 2017; 12, 4: 355-361 


\section{Piśmiennictwo}

1. Baehner T, Boehm O, Probst C, et al. Cardiopulmonary bypass in cardiac surgery. Anaesthesist. 2012; 61(10): 846-856, doi: 10.1007/ /s00101-012-2050-0, indexed in Pubmed: 22971923.

2. Yavari M, Becker RC. Anticoagulant therapy during cardiopulmonary bypass. J Thromb Thrombolysis. 2008; 26(3): 218-228, doi: 10.1007/s11239-008-0280-4, indexed in Pubmed: 18931979.

3. Sokolowska E, Kalaska B, Miklosz J, et al. The toxicology of heparin reversal with protamine: past, present and future. Expert Opin Drug Metab Toxicol. 2016; 12(8): 897-909, doi: 10.1080/17425255. 2016.1194395, indexed in Pubmed: 27223896.

4. Lee GM, Welsby IJ, Phillips-Bute B, et al. High incidence of antibodies to protamine and protamine/heparin complexes in patients undergoing cardiopulmonary bypass. Blood. 2013; 121(15): 2828-2835, doi: 10.1182/blood-2012-11-469130, indexed in Pubmed: 23422751.

5. Bakchoul T, Zöllner H, Amiral J, et al. Anti-protamine-heparin antibodies: incidence, clinical relevance, and pathogenesis. Blood. 2013; 121(15): 2821-2827, doi: 10.1182/blood-2012-10-460691, indexed in Pubmed: 23325832.

6. Al-Mondhiry H, Pierce WS, Basarab RM. Protamine-induced thrombocytopenia and leukopenia. Thromb Haemost. 1985; 53(1): 60-64, indexed in Pubmed: 3873119.

7. Schnitzler S, Renner H, Pfüller U. Histamine release from rat mast cells induced by protamine sulfate and polyethylene imine. Agents Actions. 1981; 11(1-2): 73-74, indexed in Pubmed: 6166172.

8. Shastri KA, Logue GL, Stern MP, et al. Complement activation by heparin-protamine complexes during cardiopulmonary bypass: effect of C4A null allele. J Thorac Cardiovasc Surg. 1997; 114(3): 482-488, doi: 10.1016/S0022-5223(97)70197-1, indexed in Pubmed: 9305203.

9. Stewart WJ, McSweeney SM, Kellett MA, et al. Increased risk of severe protamine reactions in NPH insulin-dependent diabetics undergoing cardiac catheterization. Circulation. 1984; 70(5): 788-792, indexed in Pubmed: 6488493.

10. Adourian U, Shampaine EL, Hirshman CA, et al. High-titer protamine-specific IgG antibody associated with anaphylaxis: report of a case and quantitative analysis of antibody in vasectomized men. Anesthesiology. 1993; 78(2): 368-372, indexed in Pubmed: 8439034.

11. Collins C, O'Donnell A. Does an allergy to fish pre-empt an adverse protamine reaction? A case report and a literature review. Perfusion. 2008; 23(6): 369-372, doi: 10.1177/0267659109105543, indexed in Pubmed: 19454566.

12. Chudasama SL, Espinasse B, Hwang F, et al. Heparin modifies the immunogenicity of positively charged proteins. Blood. 2010; 116(26): 6046-6053, doi: 10.1182/blood-2010-06-292938, indexed in Pubmed: 20852126.

13. Bakchoul T, Giptner A, Krautwurst A, et al. In vivo animal model of drug-induced thrombocytopenia: the clinical relevance of anti-protamine sulfate antibodies. J Thromb Haemost. 2011; 9(S2).

14. Arepally G, Cines DB. Pathogenesis of heparin-induced thrombocytopenia and thrombosis. Autoimmun Rev. 2002; 1(3): 125-132, indexed in Pubmed: 12849005.

15. Rauova L, Zhai Li, Kowalska MA, et al. Role of platelet surface PF4 antigenic complexes in heparin-induced thrombocytopenia pathogenesis: diagnostic and therapeutic implications. Blood. 2006; 107(6): 2346-2353, doi: 10.1182/blood-2005-08-3122, indexed in Pubmed: 16304054.
16. Rauova L, Hirsch JD, Greene TK, et al. Monocyte-bound PF4 in the pathogenesis of heparin-induced thrombocytopenia. Blood. 2010; 116(23): 5021-5031, doi: 10.1182/blood-2010-03-276964, indexed in Pubmed: 20724543.

17. Cines DB, Tomaski A, Tannenbaum S. Immune endothelial-cell injury in heparin-associated thrombocytopenia. N Engl J Med. 1987; 316(10): 581-589, doi: 10.1056/NEJM198703053161004, indexed in Pubmed: 3807952.

18. Kowalska MA, Krishnaswamy S, Rauova L, et al. Antibodies associated with heparin-induced thrombocytopenia (HIT) inhibit activated protein C generation: new insights into the prothrombotic nature of HIT. Blood. 2011; 118(10): 2882-2888, doi: 10.1182/blood-2011-02-335208, indexed in Pubmed: 21772054.

19. Panzer S, Schiferer A, Steinlechner B, et al. Serological features of antibodies to protamine inducing thrombocytopenia and thrombosis. Clin Chem Lab Med. 2015; 53(2): 249-255, doi: 10.1515/cclm-2014 0664, indexed in Pubmed: 25153412.

20. Singla A, Sullivan MJ, Lee G, et al. Protamine-induced immune thrombocytopenia. Transfusion. 2013; 53(10): 2158-2163, doi: 10.1111/ /trf.12112, indexed in Pubmed: 23384227.

21. Butterworth J, Lin YA, Prielipp R, et al. The pharmacokinetics and cardiovascular effects of a single intravenous dose of protamine in normal volunteers. Anesth Analg. 2002; 94(3): 514-522; table of contents, indexed in Pubmed: 11867368.

22. Warkentin TE, Warkentin TE, Greinacher A, et al. Delayed-onset heparin-induced thrombocytopenia and thrombosis. Ann Intern Med. 2001; 135(7): 502-506, indexed in Pubmed: 11578153.

23. Teoh $\mathrm{KH}$, Young E, Bradley CA, et al. Heparin binding proteins. Contribution to heparin rebound after cardiopulmonary bypass. Circulation. 1993; 88(5 Pt 2): ॥420-॥425, indexed in Pubmed: 8222188.

24. Nurden P, Poujol C, Durrieu-Jais C, et al. Labeling of the internal pool of GP IIb-Illa in platelets by c7E3 Fab fragments (abciximab): flow and endocytic mechanisms contribute to the transport. Blood. 1999; 93(5): 1622-1633, indexed in Pubmed: 10029591.

25. Heyns AD, Lötter MG, Badenhorst PN, et al. Kinetics and in vivo redistribution of (111)Indium-labelled human platelets after intravenous protamine sulphate. Thromb Haemost. 1980; 44(2): 65-68, indexed in Pubmed: 7455993.

26. Greinacher A, Fuerll B, Zinke $\mathrm{H}$, et al. Megakaryocyte impairment by eptifibatide-induced antibodies causes prolonged thrombocytopenia. Blood. 2009; 114(6): 1250-1253, doi: 10.1182/ /blood-2009-02-203034, indexed in Pubmed: 19429867.

27. Pouplard C, Leroux D, Rollin J, et al. Incidence of antibodies to protamine sulfate/heparin complexes incardiac surgery patients and impact on platelet activation and clinical outcome. Thromb Haemost. 2013; 109(6): 1141-1147, doi: 10.1160/TH12-11-0844, indexed in Pubmed: 23636177.

28. Zöllner H, Jouni R, Panzer S, et al. Platelet activation in the presence of neutral protamine Hagedorn insulin: a new feature of antibodies against protamine/heparin complexes. Journal of Thrombosis and Haemostasis. 2016; 15(1): 176-184, doi: 10.1111/jth.13547.

29. Warkentin TE, Kelton JG. A 14-year study of heparin-induced thrombocytopenia. Am J Med. 1996; 101(5): 502-507, indexed in Pubmed: 8948273.

30. Linkins LA, Dans AL, Moores LK, et al. Treatment and prevention of heparin-induced thrombocytopenia: Antithrombotic Therapy and Prevention of Thrombosis, 9th ed: American College of Chest Phy- 
sicians Evidence-Based Clinical Practice Guidelines. Chest. 2012; 141(2 Suppl): e495S-e530S, doi: 10.1378/chest.11-2303, indexed in Pubmed: 22315270.

31. Watson H, Davidson S, Keeling D, et al. Haemostasis and Thrombosis Task Force of the British Committee for Standards in Haematology. Guidelines on the diagnosis and management of heparin-induced thrombocytopenia: second edition. Br J Haematol. 2012; 159(5): 528-540, doi: 10.1111/bjh.12059, indexed in Pubmed: 23043677.

32. Lewis $B E$, Wallis DE, Hursting MJ, et al. Effects of argatroban therapy, demographic variables, and platelet count on thrombotic risks in heparin-induced thrombocytopenia. Chest. 2006; 129(6): 1407-1416, doi: 10.1378/chest.129.6.1407, indexed in Pubmed: 16778256.

33. Magnani HN, Gallus A. Heparin-induced thrombocytopenia (HIT). A report of 1,478 clinical outcomes of patients treated with danaparoid (Orgaran) from 1982 to mid-2004. Thromb Haemost. 2006; 95(6): 967-981, doi: 10.1160/TH05-07-0489, indexed in Pubmed: 16732376.

34. Warkentin TE, Maurer BT, Aster RH. Heparin-induced thrombocytopenia associated with fondaparinux. N Engl J Med. 2007; 356(25): 2653-2655; discussion 2653, doi: 10.1056/NEJMc070346, indexed in Pubmed: 17582083.

35. Greinacher A. Heparin-Induced Thrombocytopenia. New England Journal of Medicine. 2015; 373(3): 252-261, doi: 10.1056/nejmcp1411910.

36. Linkins LA, Warkentin TE, Pai M, et al. Design of the rivaroxaban for heparin-induced thrombocytopenia study. J Thromb Thrombolysis. 2014; 38(4): 485-492, doi: 10.1007/s11239-014-1064-7, indexed in Pubmed: 24549975.

37. Abo-Salem E, Becker RC. Reversal of novel oral anticoagulants. Curr Opin Pharmacol. 2016; 27: 86-91, doi: 10.1016/j.coph.2016.02.008, indexed in Pubmed: 26939028.

38. Reilly MP, Sinha U, André P, et al. PRT-060318, a novel Syk inhibitor, prevents heparin-induced thrombocytopenia and thrombosis in a transgenic mouse model. Blood. 2011; 117(7): 2241-2246, doi: 10.1182/blood-2010-03-274969, indexed in Pubmed: 21088136.
39. Stolla M, Stefanini L, André P, et al. CalDAG-GEFI deficiency protects mice in a novel model of Fcy RIIA-mediated thrombosis and thrombocytopenia. Blood. 2011; 118(4): 1113-1120, doi: 10.1182/ /blood-2011-03-342352, indexed in Pubmed: 21652673.

40. Shenoi RA, Kalathottukaren MT, Travers RJ, et al. Affinity-based design of a synthetic universal reversal agent for heparin anticoagulants. Sci Transl Med. 2014; 6(260): 260ra150, doi: 10.1126/ /scitransImed.3009427, indexed in Pubmed: 25355700.

41. Kalaska B, Sokolowska E, Kaminski K, et al. Cationic derivative of dextran reverses anticoagulant activity of unfractionated heparin in animal models of arterial and venous thrombosis. Eur J Pharmacol. 2012; 686(1-3): 81-89, doi: 10.1016/j.ejphar.2012.04.037, indexed in Pubmed: 22579410.

42. Kalaska B, Kaminski K, Sokolowska E, et al. Nonclinical evaluation of novel cationically modified polysaccharide antidotes for unfractionated heparin. PLoS One. 2015; 10(3): e0119486, doi: 10.1371/journal. pone.0119486, indexed in Pubmed: 25781030.

43. Sokolowska E, Kalaska B, Kaminski K, et al. The Toxicokinetic Profile of Dex40-GTMAC3-a Novel Polysaccharide Candidate for Reversal of Unfractionated Heparin. Front Pharmacol. 2016; 7: 60, doi: 10.3389/ /fphar.2016.00060, indexed in Pubmed: 27014072.

44. Kamiński K, Płonka M, Ciejka J, et al. Cationic derivatives of dextran and hydroxypropylcellulose as novel potential heparin antagonists. J Med Chem. 2011; 54(19): 6586-6596, doi: 10.1021/jm200380w, indexed in Pubmed: 21866887.

45. Kalaska B, Kaminski K, Miklosz J, et al. Heparin-binding copolymer reverses effects of unfractionated heparin, enoxaparin, and fondaparinux in rats and mice. Transl Res. 2016; 177: 98-112.e10, doi: 10.1016/j.trsl.2016.06.009, indexed in Pubmed: 27456749.

46. Joglekar MV, Quintana Diez PM, Marcus S, et al. Disruption of PF4/H multimolecular complex formation with a minimally anticoagulant heparin (ODSH). Thromb Haemost. 2012; 107(4): 717-725, doi: 10.1160/TH11-11-0795, indexed in Pubmed: 22318669.

47. Jouni $\mathrm{R}$, Zöllner $\mathrm{H}$, Khadour A, et al. Partially desulfated heparin modulates the interaction between anti-protamine/heparin antibodies and platelets. Thromb Haemost. 2016; 115(2): 324-332, doi: 10.1160/ /TH15-07-0539, indexed in Pubmed: 26423467. 